\title{
Short term inhalation exposure to turpentine: toxicokinetics and acute effects in men
}

\author{
Agneta Falk Filipsson
}

\begin{abstract}
Objectives-This study describes the toxicokinetics, pulmonary function, and subjective ratings of discomfort in volunteers experimentally exposed to turpentine vapour (a mixture of monoterpenes). The results were compared with similar exposure to single monoterpenes to look in the toxicokinetics and acute effects for signs of interactions between the monoterpenes.
\end{abstract}

Methods-Eight male volunteers were exposed to $450 \mathrm{mg} / \mathrm{m}^{3}$ turpentine by inhalation $(2 \mathrm{~h}, 50 \mathrm{~W})$ in an exposure chamber.

Results-The mean relative uptakes of $\alpha$ pinene, $\beta$-pinene, and 3-carene were $62 \%$, $66 \%$, and $68 \%$ respectively, of the amount supplied. Between $2 \%$ and $5 \%$ of the net uptake was excreted unchanged in the expired air after the end of exposure. The mean blood clearance 21 hours after exposure $\left(C_{21 h}\right)$ of $\alpha$-pinene, $\beta$-pinene and 3carene, were $0.8,0.5$, and $0.41 . \mathrm{kg}^{-1} . \mathrm{h}^{-1}$, respectively. The mean half lives $\left(t_{1 / 2}\right)$ of the last phase of $\alpha$-pinene, $\beta$-pinene, and 3 -carene averaged 32,25 , and 42 hours, respectively. The $t_{1 / 2} s$ agreed with previously calculated half lives from single exposures. The total blood clearance $\mathbf{C L}_{21 \mathrm{~h}}$ of 3-carene found in this turpentine study was lower, and $\mathrm{CL}_{4 \mathrm{~h}}$ of 3-carene was significantly lower than the values obtained from similar exposure to pure 3-carene. The subjects attending both exposure to turpentine and to pure $\alpha$-pinene at 450 $\mathrm{mg} / \mathrm{m}^{3}$ had lower $\mathrm{CL}_{4 \mathrm{~h}}$ during the exposure to turpentine, when they experienced more discomfort of the throat or the airways $(F=5 \cdot 7, P=0.048)$ than during exposure to control concentrations. After experimental exposure to turpentine an increase in airway resistance was found that differed significantly from results of exposure to 3 -carene at $10 \mathrm{mg} / \mathrm{m}^{3}(P=$ $0.021)$ or $450 \mathrm{mg} / \mathrm{m}^{3}(P=0.047)$.

Conclusions-Toxicokinetics and acute effects show small, if any, interactions between $\alpha$-pinene, $\beta$-pinene, and 3carene. The subjects experienced discomfort in the throat and airways during exposure to turpentine and airway resistance was increased after the end of exposure.

(Occup Environ Med 1996;53:100-105)
Keywords: monoterpenes; toxicokinetics; lung function

Terpenes are naturally occurring in pine trees and certain bushes. An oleoresin is obtained, as a yellow sticky gum, when the trees are tapped. After distillation of the oleoresin a volatile oily fraction, turpentine, is obtained. The main components of turpentine are the monoterpenes: $\alpha$-pinene, $\beta$-pinene, and 3carene. The composition of turpentine varies with species, location, and season. Monoterpenes are also present in gases liberated during sawing or processing of fresh wood and pose a potential exposure for workers in sawmills. Industrial exposures of $39-550$ $\mathrm{mg} / \mathrm{m}^{3}$ have been reported. ${ }^{12}$ For turpentine, a mixture of monoterpenes, and for a single monoterpene the Swedish occupational exposure limit (OEL) value is $150 \mathrm{mg} / \mathrm{m}^{3}$. At the time of the exposure the OEL was $450 \mathrm{mg} / \mathrm{m}^{3}$. In rats, terpenes accumulate in peripheral fat, kidneys, and the brain. ${ }^{34}$ The blood:air partition coefficients are 15,23 , and 32 , respectively, for $\alpha$-pinene, $\beta$-pinene, and 3 -carene. Solubility of monoterpenes in human blood is high. This should imply a high respiratory uptake. Solubility in olive oil is also high; the oil:air partition coefficients are 2900, 4300, and 5000, respectively, for $\alpha$-pinene, $\beta$ pinene, and 3-carene. This should imply accumulation in adipose tissue. ${ }^{5}$ Respiratory and percutaneous uptake of terpenes have been found in humans. ${ }^{67}$ Slow metabolism and renal elimination of monoterpenes were suggested after a patient acutely poisoned by pine oil was studied. ${ }^{8}$ Almost all the scientific literature found on monoterpenes (except for $d$ limonene) are about occupational exposure to a mixture of monoterpenes, but no quantitative study of uptake and elimination of a mixture was found. It is important to study toxicokinetics and effects of exposure to the different components in a mixture, firstly as single exposures to avoid contributions from other solvents and secondly as multiple exposures to look for signs of interactive effects between the components. High respiratory uptake of the monoterpenes $\alpha$-pinene, 3-carene, and $d$ limonene was found when human volunteers were exposed to the monoterpenes by inhalation. ${ }^{9-11}$ The monoterpenes were fairly readily metabolised and only small percentages of the total uptake were eliminated as unchanged monoterpene through the lungs and even less in the urine. Up to $4 \%$ of the total uptake of $\alpha$ pinene after human exposure by inhalation 
was eliminated in the urine as cis- and transverbenol. ${ }^{12}$ Terpenes may irritate the skin and mucous membranes ${ }^{613}$ and prolonged exposure may result in allergic contact dermatitis ${ }^{14} 15$ or chronic impairment of lung function. ${ }^{2}$

The aim of this study was to elucidate toxicokinetics, pulmonary function, and ratings of discomfort in men experimentally exposed to turpentine and to look for signs in the toxicokinetics and acute effects of interactions between the monoterpenes.

\section{Materials and methods SUBJECTS}

Eight healthy men, not occupationally exposed to solvents, with a mean (range) age of $28(18-37)$ years and weight of $75(62-83)$ $\mathrm{kg}$ participated in the study. All were nonsmokers and they were instructed to refrain from alcohol and activities that could cause exposure to organic solvents during the preceding two days and throughout the experiment. The study was approved by the regional ethics committee at the Karolinska Institute (Solna, Sweden)

\section{EXPOSURE CONDITIONS}

The subjects were exposed to turpentine (Swedish turpentine, Alcro Beckers) for two hours at the Swedish OEL then in force $\left(450 \mathrm{mg} / \mathrm{m}^{3}\right.$ (75 ppm)) during light physical exercise $(50 \mathrm{~W}$ on a bicycle ergometer). The exposure was conducted in an exposure chamber as described earlier for 3-carene and $d$ limonene. ${ }^{1011}$ A low concentration of 3-carene, $10 \mathrm{mg} / \mathrm{m}^{3}$, was used as a control. The control concentration was chosen as low as possible so that no effect was to be expected, but the subjects could still smell the solvent. Thus they did not know what concentration they were exposed to. The workload $50 \mathrm{~W}$ was chosen to imitate the physical activity generally found in light industries. ${ }^{1617}$ The solvent concentration in the air of the chamber was continuously monitored at atmospheric pressure by an infrared spectrophotometer (Miran 80) equipped with a $20 \mathrm{~m}$ thermostatically controlled $\left(45^{\circ} \mathrm{C}\right)$ gas cell. Measurements of monoterpenes in the air of the chamber were made at $3.39 \mu \mathrm{m}$ with $3.6 \mu \mathrm{m}$ as the reference wavelength. The concentration of monoterpenes varied by less than $2 \%$ during the two hour exposure of turpentine and less than $3 \%$ between different days. The mean temperature in the chamber was $21^{\circ} \mathrm{C}$ and varied by less than $2.5^{\circ} \mathrm{C}$ during a two hour exposure to turpentine and between different days. Earlier exposures to monoterpenes performed in a similar way were used for comparison between monoterpenes..$^{9} 10$

\section{MEASUREMENTS AND ANALYSIS}

Air sampling and analysis

At four regular time intervals during the exposure exhaled air was individually collected in polyester laminated aluminium foil bags (about 20 1) for about four minutes each. Exhaled air samples were also collected after exposure $(5,15,25,85,150$, and 230 minutes after the end of exposure). The volume of the expired air was measured with a balanced spirometer and the concentrations of monoterpenes were analysed on a gas chromatograph (Carlo Erba, Fractovap 2350) equipped with a flame ionisation detector and a polar column (Supelcowax 10, $30 \mathrm{~m}, 0.75 \mathrm{~mm}$ inner diameter). The injector and detector temperatures were $200^{\circ} \mathrm{C}$ and the column temperature was $80^{\circ} \mathrm{C}$. Nitrogen at a flow rate of $5 \mathrm{ml} / \mathrm{min}$ was used as the carrier gas. The mean value of the four sampling periods was used to calculate the total uptake of monoterpenes during the entire exposure period, which was calculated as the difference between the total amount of monoterpenes in inhaled and exhaled air. The pulmonary ventilation $\left(\mathrm{V}_{\mathrm{E}}\right)$ was measured as the collected volume of air, corrected to body temperature and pressure (BTPS) divided by the collection time of the volume measured. $\mathrm{TheV}_{\mathrm{E}} \mathrm{BTPS}$ was measured at rest before and after exposure and at exercise during the exposure. Heart rate was continuously recorded during the exposure with a heart rate meter (Sport tester PE3000, Polar Electro, Finland).

\section{Blood sampling and analysis}

Arterial capillary blood $(200 \mu \mathrm{l})$ was collected from a prewarmed fingertip at selected intervals during the exposure and up to 21 hours after end of exposure, for measurement of monoterpenes in blood. Blood sampling during exposure was taken by the subject holding out one hand through a closable hole in the wall. Blood samples were collected in heparinised capillary tubes $(2 \times 100 \mu \mathrm{l})$ and transferred to gas tight head space vials $(22 \cdot 4$ $\mathrm{ml}$ ) which were capped immediately with Teflon lined membranes. The samples were kept for 20 minutes at $37^{\circ} \mathrm{C}$ before analysis. The headspace of the blood samples was analysed on a gas chromatograph (Perkin Elmer 8700) equipped with a head space autosampler (Perkin Elmer HS-101), a polar column (Supelcowax 10, $30 \mathrm{~m}, 0.75 \mathrm{~mm}$ inner diameter), and a flame ionisation detector. The injector temperature was $170^{\circ} \mathrm{C}$ and the detector temperature was $240^{\circ} \mathrm{C}$. The initial temperature of the column was $80^{\circ} \mathrm{C}$; after two minutes it was increased by $5^{\circ} \mathrm{C} / \mathrm{min}$ to $100^{\circ} \mathrm{C}$ and then by $25^{\circ} \mathrm{C} / \mathrm{min}$ to $210^{\circ} \mathrm{C}$. Nitrogen at a flow rate of $5 \mathrm{ml} / \mathrm{min}$ was used as the carrier gas. The concentration of monoterpenes in the blood was measured by comparison with individual standard curves prepared in the same concentration range by adding monoterpenes to blood samples taken before the exposure. The detection limit was $0.06 \mu \mathrm{mol} / 1$, and the relative error of the method was $4 \%$, based on 10 duplicate samples within the relevant concentration range.

\section{TOXICOKINETIC CALCULATIONS}

Apparent blood clearance (CL) was calculated as the quotient between the total uptake (dose) and the area under the blood concentration $v$ time curve (AUC), and was adjusted to body weight. To obtain the AUC, areas for each experiment were calculated by the trapesoidal method from the start of exposure to 
the time the blood samples were taken four and 21 hours after exposure. Thereafter areas to infinity were calculated as the quotient between the line estimate of the monoterpene concentration in blood at four and 21 hours after exposure, and the slope was calculated by linear regression of the log linear blood concentration $v$ the time curve of the last phase. The concentrations of turpentine, $\alpha$-pinene, and 3-carene in blood were measured until 21 hours after exposure to $450 \mathrm{mg} / \mathrm{m}^{3}$. At lower exposure concentrations of $\alpha$-pinene and 3-carene the concentration in blood could only be detected until four hours after exposure because the blood concentrations of the monoterpenes were low and close to the detection limit. To allow comparisons between different exposure concentrations, $\mathrm{CL}_{4 \mathrm{~h}} \mathrm{~s}$ based on $\mathrm{AUC}_{0-4 \mathrm{~h}}$ were found; the $\mathrm{AUC}_{0-4 \mathrm{~h}}$ was calculated for all exposures of monoterpenes. In this case, the last section of the blood concentration time curve is neglected, AUC is underestimated and clearance thus overestimated. The values that included the last phase of $\mathrm{CL}_{21}$ s are probably more accurate but may still be somewhat overestimated for the same reason.

Individual semilogarithmic plots of the elimination from blood $v$ time for monoterpene concentration were treated by the method of residuals. Linear phases were distinguished by best fit with the end phase subtracted. The slopes of the phases were calculated by linear regression and converted into $t_{1 / 2} s$.

The amount of solvent exhaled after the end of exposure was estimated from the AUC of concentration of monoterpenes in expired air $v$ time and multiplied by the ventilation. The AUC of exhaled air was calculated as described for the blood samples.

\section{RATINGS OF SYMPTOMS}

Before, during, and after each exposure the subjects rated the level of perceived discomfort in 10 questions. Ratings were performed with a $100 \mathrm{~mm}$ visual analogue scale graded from no effect to almost unbearable. ${ }^{18}$ The questions included irritative symptoms such as: (a) discomfort in the eyes (burning, irritation, or running eyes); (b) discomfort in the nose (burning, irritation, or running nose); (c) discomfort in the throat or airways; and symptoms related to the central nervous system such as: $(d)$ headache; $(e)$ fatigue; $(f)$ sickness feeling; $(g)$ dizziness; $(h)$ intoxication; ( $i$ difficulty in breathing; and finally $(j)$ smell of solvent.

\section{PULMONARY FUNCTION}

Pulmonary function was assessed with a constant volume, variable pressure, body plethysmograph (Jaeger Masterlabbody, Erich Jaeger GmbH, Würzburg, Germany), equipped with a pneumotachograph system for forced expiratory volume measurements. The following variables were measured: forced expiratory volume in one second $\left(\mathrm{FEV}_{1}\right)$, vital capacity (VC), peak expiratory flow, residual volume, total lung capacity, mean expiratory flow at $50 \%\left(\mathrm{MEF}_{50}\right)$, and airway's resistance. The subject confined in the box generates a pressure change by volume displacement of several $\mathrm{ml}$ during breathing. The aim of this test is a precise measurement of the volume displacement. The breathing frequency was 30 per minute. Airway resistance was measured before spirometry and specific conductance was calculated from airway resistance and corrected for lung volume. Measurements were carried out immediately before exposure and between 20 and 30 minutes after the end of exposure. To measure the effect of exposure to turpentine and 3-carene at 450 and $10 \mathrm{mg} / \mathrm{m}^{3}$, the individual differences between values after and before exposure were divided by the individual values before exposure and presented as the means.

\section{STATISTICAL EVALUATION}

The respiratory and toxicokinetic variables were analysed both with the Wilcoxon signed rank test and Student's $t$ test for paired analysis (two sided test) with Statview 4.02 on an Apple Macintosh. For comparison between exposure to $\alpha$-pinene and turpentine no statistical evaluation was made because four of the subjects attended both studies whereas the other subjects only participated in one of the studies. Thus, neither paired nor unpaired analysis could be made. To investigate the subjective ratings, given by all the subjects

Table 1 Mean (SD) experimental results of some physiological and toxicokinetic variables from two hour inhalation exposure to $450 \mathrm{mg} / \mathrm{m}^{3}$ of turpentine during physical exercise at a workload of $50 \mathrm{~W}$ (also, results from previous single exposure to $\alpha$-pinene and 3-carena are presented)

\begin{tabular}{|c|c|c|c|c|c|c|c|}
\hline & \multicolumn{3}{|l|}{$\alpha$-pinene } & \multirow{2}{*}{$\begin{array}{l}\beta \text {-Pinene } \\
\text { Exposure to } \\
\text { turpentine }\end{array}$} & \multicolumn{3}{|l|}{ 3-carene } \\
\hline & $\begin{array}{l}\text { Exposure to } \\
\text { turpentine }\end{array}$ & $\begin{array}{l}\text { Exposure to } \\
\alpha \text {-pinene }\end{array}$ & $\begin{array}{l}\text { Exposure to } \\
\alpha \text {-pinene } e^{9}\end{array}$ & & $\begin{array}{l}\text { Exposure to } \\
\text { turpentine }\end{array}$ & $\begin{array}{l}\text { Exposure to } \\
\text { 3-carene } e^{10}\end{array}$ & $\begin{array}{l}\text { Exposure to } \\
\text { 3-carene }\end{array}$ \\
\hline Air concentration & $242(3 \cdot 3)$ & $455(5 \cdot 3)$ & $225(5 \cdot 1)$ & $49(0 \cdot 67)$ & $157(2 \cdot 1)$ & $451(5 \cdot 8)$ & $228(5 \cdot 8)$ \\
\hline $\begin{array}{l}\text { Heart ratef } \\
\quad \text { (beats/min) } \\
\text { Pulm ventilation }\end{array}$ & $89(10)$ & $88(9)$ & $87(10)$ & - & - & $92(11)$ & $90(9)$ \\
\hline $\begin{array}{l}\text { (1/min) } \\
\text { Net uptake }\end{array}$ & $24(2 \cdot 8)$ & $26(4 \cdot 5)$ & $25(3 \cdot 8)$ & - & - & $23(1 \cdot 6)$ & $24(2 \cdot 7)$ \\
\hline (\% of total inhaled) & $62(5 \cdot 3)$ & $58(5 \cdot 3)$ & $60(3.9)$ & $66(5 \cdot 8)$ & $68(7 \cdot 5)$ & $71(4 \cdot 7)$ & $70(4 \cdot 4)$ \\
\hline (\% of net uptake) & $3 \cdot 8(1 \cdot 1)$ & $7 \cdot 7(3 \cdot 1)$ & $5 \cdot 7(5 \cdot 7)$ & $5 \cdot 0(5 \cdot 8)$ & $2.4(1.5)^{\star}$ & $4.8(1 \cdot 2)$ & $1.9(1.5)$ \\
\hline $\begin{array}{l}\text { Concentrations steady state } \\
\text { states }(\mu \mathrm{mol} / \mathrm{l})\end{array}$ & $9.0(0.75)$ & $19(3 \cdot 6)$ & $9.6(1.9)$ & $2.6(0.29)$ & $9.9(0.89)$ & $25(0.92)$ & $12(1 \cdot 4)$ \\
\hline
\end{tabular}

$\star \mathrm{P}<0.05$, Student's $t$ test $v$ pure 3-carene $\left(450 \mathrm{mg} / \mathrm{m}^{3}\right)$.

†During exposure; $\ddagger$ after exposure; lmean from last 30 minutes of exposure. 


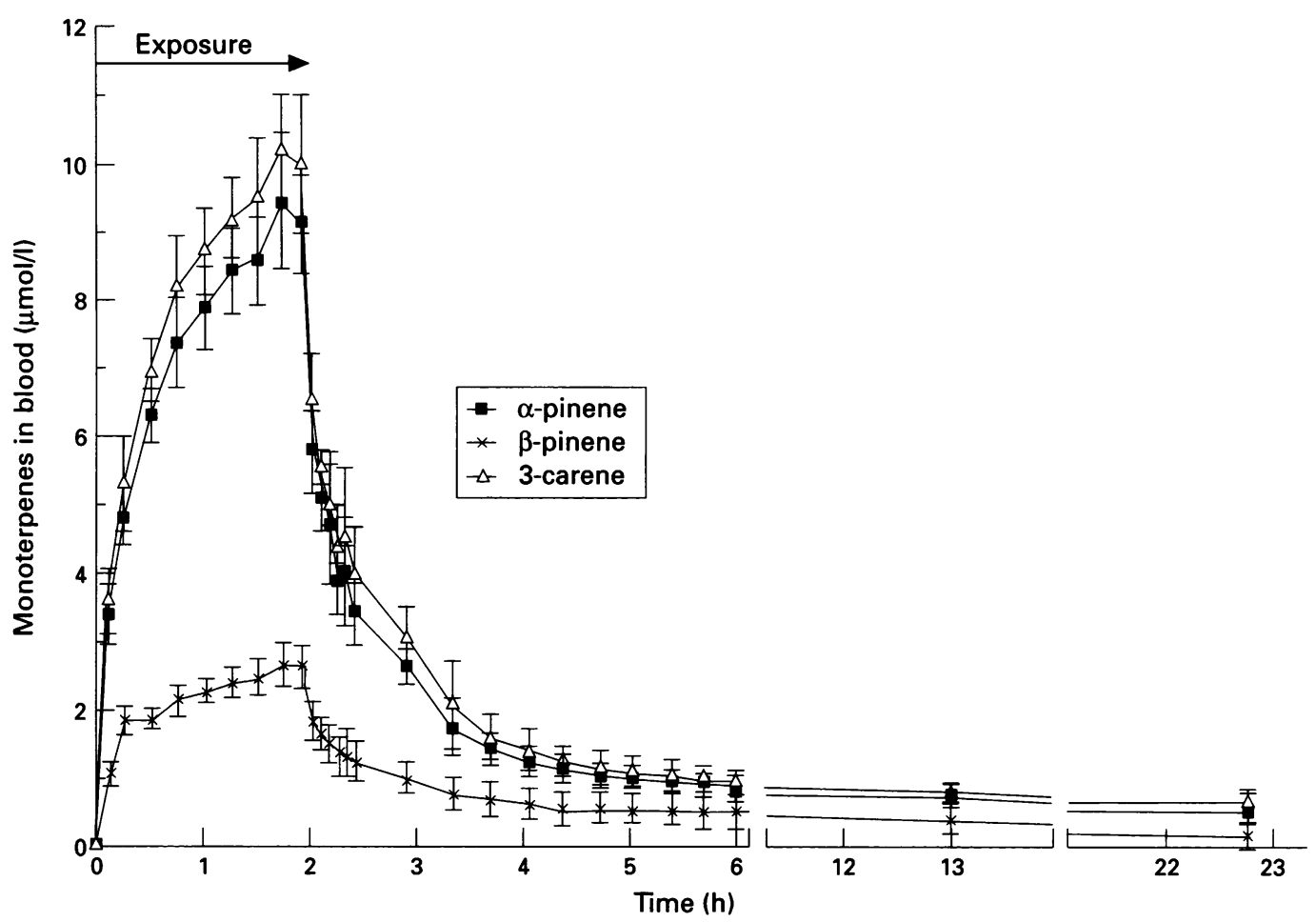

Concentration of $\alpha$-pinene, $\beta$-pinene, and 3-carene in arterial capillary blood during and after exposure $(2 h, 50 W)$ to turpentine at a concentration of $450 \mathrm{mg} / \mathrm{m}^{3}$. Mean (SD) of eight subjects are given.

during the exposures, analyses of variance was performed with SuperANOVA. The level of statistical significance was set to $0 \cdot 05$. Unless otherwise stated results are presented as mean (SD).

\section{Results}

The mean total concentration of the monoterpenes in the air of the chamber from all the turpentine exposures was $449 \mathrm{mg} / \mathrm{m}^{3}$, with a relative $S D$ of $1.4 \%$, based on air concentrations from four different occasions at each exposure. Correcting for pulmonary ventilation this indicates that the mean amount of turpentine delivered was $8.5 \mathrm{mmol}$. Other substances in the turpentine were not detected and, if the assumption is made that the turpentine consists of $\alpha$-pinene, $\beta$-pinene, and 3carene, the proportions of the vapour were about $54 \%, 11 \%$, and $35 \%$, respectively (table 1). The relative net uptakes of the total inhaled $\alpha$-pinene, $\beta$-pinene, and 3-carene averaged $62 \%, 66 \%$, and $68 \%$ respectively (table 1 ). Between $2 \%$ and $8 \%$ of the net

Table 2 Apparent $C L s$ and $t_{1 / 2}$ of $\alpha$-pinene, $\beta$-pinene, and 3-carene from two hour inhalation exposure to $450 \mathrm{mg} / \mathrm{m}^{3}$ of $\alpha$-pinene, $\beta$-pinene, 3-carene or turpentine during physical exercise at a workload of $50 \mathrm{~W}$ (mean (SD) from eight subjects are given)

\begin{tabular}{|c|c|c|c|c|c|}
\hline & \multicolumn{2}{|l|}{$\alpha$-pinene } & \multirow{2}{*}{$\begin{array}{l}\text { B-pinene } \\
\text { Exposure to } \\
\text { turpentine }\end{array}$} & \multicolumn{2}{|l|}{ 3-carene } \\
\hline & $\begin{array}{l}\text { Exposure to } \\
\text { turpentine }\end{array}$ & $\begin{array}{l}\text { Exposure to } \\
\alpha \text {-pinene } e^{9}\end{array}$ & & $\begin{array}{l}\text { Exposure to } \\
\text { turpentine }\end{array}$ & $\begin{array}{l}\text { Exposure to } \\
\text { 3-carene } e^{10}\end{array}$ \\
\hline $\begin{array}{l}\mathrm{CL}_{4 \mathrm{hr}}\left(1 . \mathrm{kg}^{-1} \cdot \mathrm{h}^{-1}\right) \dagger \\
\mathrm{CL}_{21 \mathrm{hr}}\left(\mathrm{l} \cdot \mathrm{kg}^{-1} \cdot \mathrm{h}^{-1}\right) \ddagger \\
\mathrm{t}_{1 / 2} \text { initial }(\mathrm{min}) \ddagger \\
\mathrm{t}_{1 / 2} \text { middle }(\mathrm{min}) \ddagger \\
\mathrm{t}_{1 / 2} \text { terminal }(\mathrm{h}) \ddagger\end{array}$ & $\begin{array}{l}1.6(0 \cdot 3) \\
0.8(0 \cdot 09) \\
4 \cdot 1(2 \cdot 8) \\
33 \cdot 4(4 \cdot 1) \\
32(18)\end{array}$ & $\begin{array}{l}1 \cdot 4(0 \cdot 31) \\
1 \cdot 1(0 \cdot 20) \\
4 \cdot 8(1 \cdot 5) \\
38(8 \cdot 2) \\
12(4)\end{array}$ & $\begin{array}{l}0 \cdot 8(0 \cdot 3) \\
0 \cdot 5(0 \cdot 3) \emptyset \\
5 \cdot 3(3 \cdot 0) \\
41(15) \\
25(18)\end{array}$ & $\begin{array}{l}1 \cdot 0(0 \cdot 2) \star \\
0 \cdot 4(0 \cdot 1) \oint \\
3 \cdot 1(0 \cdot 7) \\
33(6 \cdot 2) \\
42(23)\end{array}$ & $\begin{array}{l}1.3(0 \cdot 1) \\
0.9(0 \cdot 3) \\
4.5(1 \cdot 5) \\
35(5 \cdot 7) \\
30(22)\end{array}$ \\
\hline
\end{tabular}

${ }^{\star} \mathrm{P}<0.05$ Student's $t$ test $v$ pure 3-carene exposure.

†Based on AUC from values measured up to $4 \mathrm{~h}$ after exposure; $\ddagger$ based on AUC from values measured up to $21 \mathrm{~h}$ after exposure; §four subjects due to analytical problems resulting in problems calculating AUC. uptake was excreted unchanged in the expired air after the end of exposure (table 1). Respiratory elimination of 3-carene was significantly higher after exposure to $450 \mathrm{mg} / \mathrm{m}^{3}$ of 3 -carene than after exposure to turpentine ( $P$ $=0.01$ ).

During the exposure the arterial blood concentration increased rapidly initially and then levelled off toward the end of exposure (figure). The decay was similarly rapid and after the end of exposure three log linear phases could be distinguished visually during the time studied. There was an initial phase (0-15 min after the end of exposure), a middle phase (16-197 $\mathrm{min}$ after the end of exposure) and a last phase (3.3-21.3 h after the end of exposure). Table 2 shows the $t_{1 / 2}$ of the three phases. The $t_{1 / 2}$ of the initial and middle phases agreed with earlier results from exposure to single monoterpenes whereas the average $t_{1 / 2}$ of the last phases of $\alpha$-pinene and 3 -carene tended to be higher in this present study (table 2 ). The $\mathrm{CL}_{21 \mathrm{~h}}$ from blood samples taken during exposure and until $21 \mathrm{~h}$ after exposure was lower for turpentine exposure $\left(0 \cdot 41 . \mathrm{kg}^{-1} \cdot \mathrm{h}^{-1}\right)$ than for similar exposure to $3-$ carene alone $\left(0.91 . \mathrm{kg}^{-1} \cdot \mathrm{h}^{-1)}\right.$, but this difference was not significant (table 2). The $\mathrm{CL}_{4 \mathrm{~h}}$ from blood samples taken during exposure and until four hours after exposure was significantly lower $(P=0.02)$ after multiple exposure $\left(1.0 \mathrm{l} . \mathrm{kg}^{-1} \cdot \mathrm{h}^{-1}\right)$ than after single exposure $\left(1 \cdot 31 . \mathrm{kg}^{-1} \cdot \mathrm{h}^{-1}\right)$. The mean $\mathrm{CL}_{4 \mathrm{~h}}$, however, was higher for turpentine exposure $\left(1 \cdot 61 . \mathrm{kg}^{-1} \cdot \mathrm{h}^{-1}\right)$ than for single $\alpha$-pinene exposure, $\left(1.41 . \mathrm{kg}^{-1} \cdot \mathrm{h}^{-1}\right)$ but the subjects who were attending both exposure conditions showed lower $\mathrm{CL}_{4 \mathrm{~h}}$ for $\alpha$-pinene during exposure to turpentine than during exposure to $\alpha$-pinene on its own. 
Table 3 Mean (SD) lung function variables before exposure and about 30 minutes after two hours inhalation exposure to terpentine at a concentration of $450 \mathrm{mg} / \mathrm{m}^{3}$, during physical exercise at a workload of $50 \mathrm{~W}$ (values are of six subjects (seven for 3-carene exposure))

\begin{tabular}{|c|c|c|c|c|c|}
\hline & \multirow{2}{*}{\multicolumn{2}{|c|}{ Turpentine }} & \multicolumn{3}{|c|}{ Effect of exposure (change as \% of before exposure value) } \\
\hline & & & \multirow{2}{*}{$\begin{array}{l}\text { Turpentine } \\
\left(450 \mathrm{mg} / \mathrm{m}^{3}\right)\end{array}$} & \multirow{2}{*}{$\begin{array}{l}\text { 3-Carene } \\
\left(450 \mathrm{mg} / \mathrm{m}^{3}\right)^{10}\end{array}$} & \multirow{2}{*}{$\begin{array}{l}\text { 3-Carene } \\
\left(450 \mathrm{mg} / \mathrm{m}^{3}\right)^{10}\end{array}$} \\
\hline & Before exposure & After exposure & & & \\
\hline $\mathrm{VC}_{\max }(1)$ & $6 \cdot 3(1 \cdot 0)$ & $6 \cdot 1(1 \cdot 1)$ & $-1 \cdot 8(2 \cdot 2)$ & $-0.34(2 \cdot 1)$ & $0.08(1.8)$ \\
\hline FVC (1) & $6 \cdot 3(1 \cdot 0)$ & $6 \cdot 2(1 \cdot 1)$ & $-1.4(2.7)$ & $-1 \cdot 1(2 \cdot 0)$ & $-1 \cdot 1(2 \cdot 6)$ \\
\hline $\mathrm{FEV}_{1}(\mathrm{l})$ & $5 \cdot 1(0.6)$ & $5 \cdot 1(0.5)$ & $1 \cdot 7(4 \cdot 2)$ & $2 \cdot 4(3 \cdot 2)$ & $2 \cdot 5(2 \cdot 1)$ \\
\hline $\mathrm{RV}$ (l) & $2 \cdot 1(0.6)$ & $2.5(0.5)$ & $28(32)$ & $20(21)$ & 26 (19) \\
\hline $\operatorname{TLC}(1)$ & $8 \cdot 4(1 \cdot 3)$ & $8.5(1.7)$ & $3.5(5 \cdot 6)$ & $3 \cdot 3(5 \cdot 1)$ & $4 \cdot 7(3 \cdot 6)$ \\
\hline $\operatorname{MEF}_{50}(1 / s)$ & $6.0(1.5)$ & $6 \cdot 0(1 \cdot 0)$ & $3 \cdot 0(7 \cdot 8)$ & $3.1(9.9)$ & $4 \cdot 9(6 \cdot 6)$ \\
\hline PEF (1/s) & $12 \cdot 4(2 \cdot 0)$ & $12 \cdot 0(1 \cdot 0)$ & $-3.8(8 \cdot 1)$ & $-1.4(6.9)$ & $1.7(10)$ \\
\hline sGaw (1/kPa.s) & $1.9(0.6)$ & $1.5(0.3)$ & $17(74)$ & $36(100)$ & $57(120)$ \\
\hline Raw (kPA.s/l) & $0 \cdot 12(0.04)$ & $0 \cdot 15(0.03)$ & $29(32)$ & $-5 \cdot 7(45)^{\star}$ & $-21(38)^{\star}$ \\
\hline
\end{tabular}

$\star \mathrm{P}<0.05$ Student's $t$ test, turpentine $v$ 3-carene exposure.

$\mathrm{FEV}_{1}=$ forced expiratory volume in 1 second $\mathrm{VC}=$ vital capacity $; \mathrm{PEF}=$ peak expiratory flow; $\mathrm{RV}=$ residual volume; TLC = total lung capacity; $\mathrm{MEF}_{50}=$ mean expiratory flow at $50 \% \mathrm{VC} ; \mathrm{Raw}=$ airway resistance; $\mathrm{sGaw}=$ conductance.

During exposure to turpentine the subjects rated more discomfort of the throat or airways $(F=5 \cdot 7, P=0.048)$ than during exposure to control conditions $\left(10 \mathrm{mg} / \mathrm{m}^{3}\right.$ of 3 -carene). The ratings were similar to those (about $5 \%$ of the scale) for exposure to $450 \mathrm{mg} / \mathrm{m}^{3}$ of 3 carene. The subjects rated more discomfort (about $10 \%$ of the scale) when exposed to $225 \mathrm{mg} / \mathrm{m}^{3}$ of 3 -carene. A small but not significant increase in discomfort of the nose (about $5 \%$ of the scale) was found during exposure to turpentine compared with control exposures. No significant difference was found in ratings of symptoms of the central nervous system after exposure to turpentine compared with ratings during control exposures.

Significant increases in airway resistance were found after experimental exposure to turpentine (table 3) compared with control exposures $(P=0.021)$ or exposure to $450 \mathrm{mg} / \mathrm{m}^{3}$ of 3-carene ( $P=0.047)$.

\section{Discussion}

The conditions during the exposures to turpentine, except for the concentration of monoterpenes and the temperature of the air in the chamber, were the same as for earlier exposures to 3 -carene ${ }^{10}$ and $\alpha$-pinene. ${ }^{9}$ All the subjects who took part in the exposure to turpentine were also exposed to 3-carene and four of them participated in the exposure to $\alpha$ pinene. The toxicokinetic variables were studied with a non-parametric method (Wilcoxon sign rank test) and a parametric method (Student's $t$ test) to investigate if there were any differences and thus an uneven distribution. A fairly good agreement was found and therefore the Student's $t$ test for paired analysis (two sided tests in Statview) was used to compare the effects on the toxicokinetics between exposures to 3-carene and turpentine.

A high net uptake of the monoterpenes was to be expected from their relatively high solubilities in blood 5 and above all from earlier exposures to single monoterpenes. ${ }^{9-11}$ Accordingly the net uptakes of $\alpha$-pinene, $\beta$ pinene, and 3-carene were high after exposure to turpentine and were in agreement with the net uptakes during exposure to single monoterpenes. The $\mathrm{CL}_{21 \mathrm{~h}}$ of 3-carene found in this turpentine study was lower, and the $\mathrm{CL}_{4 \mathrm{~h}}$ of 3-carene was significantly lower, than when obtained from similar exposure to pure 3carene. For $\alpha$-pinene the mean $\mathrm{CL}_{4 \mathrm{~h}}$ was higher after exposure to turpentine than after single exposure to $\alpha$-pinene even although the subjects who attended both exposure to turpentine and to pure $\alpha$-pinene at $450 \mathrm{mg} / \mathrm{m}^{3}$ had lower $\mathrm{CL}_{4 \mathrm{~h}} \mathrm{~s}$ for turpentine. From the high solubility of terpenes in oil one would expect accumulation in adipose tissue and thus a long $t_{1 / 2}$ in blood. The first and middle phases of the $t_{1 / 2} s$ of $\alpha$-pinene and 3-carene were in agreement with earlier single exposures. The last phase of the $t_{1 / 2} s$ tended to be longer after exposure to a mixture of terpenes. The concentration of 3-carene in arterial blood at the end of exposure was higher than the concentration of $\alpha$-pinene, even although the total inhaled was higher for $\alpha$-pinene than for 3carene. Possible explainations are the higher blood solubility of 3-carene, ${ }^{5}$ resulting in a higher rate of net uptake and lower respiratory elimination of 3-carene; the higher fat:blood partition coefficient for $\alpha$-pinene, resulting in a higher distribution rate of $\alpha$-pinene from blood to fat and a higher metabolic rate of $\alpha$ pinene. Respiratory elimination of 3-carene after exposure to turpentine was about the same as after exposure to $225 \mathrm{mg} / \mathrm{m}^{3}$ of 3 carene but significantly lower than after exposure to $450 \mathrm{mg} / \mathrm{m}^{3}$ of 3-carene $(P=0.01)$. The mean respiratory elimination of $\alpha$-pinene after exposure to turpentine was lower than the mean after exposure to single $\alpha$-pinene. However, it is not possible to compare the groups as some of the subjects attended both exposures and some only one of the exposures.

During exposure to turpentine the subjects experienced more discomfort of the throat or airways than during control exposures. The ratings were similar to those from exposure to 3-carene at the high level. ${ }^{10}$ Yet, the subjects rated even more discomfort, about twice as much, when exposed to 3-carene at the medium concentration. During exposure to 3carene the subjects experienced irritation in eyes and nose and their responses to the high concentration were significantly higher than responses during exposure to the medium and low concentration. The ratings of irritation of the eyes, during exposure to turpentine, showed a small increase at the beginning of the exposure but $\mathbf{4 0}$ minutes later there was no difference compared with control exposures. A 
small, but not significant, increase in discomfort of the nose was found, during exposure to turpentine, compared with control exposures. This increase was lower than during exposure to 3-carene at the high concentration but higher than during exposure at the medium concentration. The mean concentration of 3carene in the turpentine vapour was about one third of the concentration during high exposure to 3 -carene. Thus it is possible that the ratings of nasal irritation are related to 3carene. In the ratings of symptoms of the central nervous system no significant difference was found between exposure to turpentine and control conditions.

Significant decreases in $\mathrm{FEV}_{1}, \mathrm{FVC}$, and $\mathrm{MEF}_{50}$ were found in workers occupationally exposed to monoterpenes at a mean (range) value of $254(100-550) \mathrm{mg} / \mathrm{m}^{3}{ }^{2}$ During experimental exposure to $\alpha$-pinene ${ }^{9}$ and 3 -carene at the control concentration ${ }^{10}$ there was a decrease in airway resistance compared with before exposure. The decrease may have been caused by exercise rather than by exposure to terpenes. A tendency towards increased airway resistance was found for 3-carene at the high exposure. During experimental exposure to turpentine an increase in airway resistance was found. The differences between exposure to turpentine and 3-carene at high and control exposures were significant. Thus exposure to turpentine, and possibly 3-carene at high concentrations, may cause an increase in airway resistance that is greater than the tendency of exercise to increase airway lumen.

The main purpose of this study was to measure the toxicokinetics, pulmonary function, and ratings of discomfort in men experimentally exposed to turpentine and to look for signs of interactive effects between the monoterpenes. Based on comparisons with previous experiments involving inhalation exposure to monoterpenes the present study indicates that the interactions between toxicokinetics and acute effects of $\alpha$-pinene, $\beta$-pinene, and 3carene are small, if present at all.

I thank Zhiping Wang for carrying out the pulmonary function analysis, Elisabeth Gullstrand, and Lena Ernstgård for their skilful technical assistance, and Agneta Löf, Ewa Wigaeus Hjelm, and Gunnar Johanson for valuable discussions and criticism of the manuscript.

1 Eriksson K, Levin J-O. Identification of cis and trans verbenol in human urine after occupational exposure to terpenes. Int Arch Occup Environ Health 1990;62:379-83.

2 Hedenstierna G, Alexandersson R, Wimander K, Rosén G. Exposure to terpenes: effects on pulmonary function. Int Arch Occup Environ Health 1983;51:191-8.

3 Savolainen H, Pfäffli P. Effects on longterm turpentine inhalation on rat brain protein metabolism. Chem Biol Interact 1978;21:271-6.

4 Sperling F, Marcus WL, Collins C. Acute toxic effects of turpentine vapor on rats and mice. Toxicol Appl Pharmacol 1967;10:8-20.

5 Falk A, Gullstrand E, Löf A, Wigeaus-Hjelm E. Liquid/air partition coefficients of four terpenes. Br f Ind Med 1990; 47:62-4.

6 Sandmeyer EE. Alicyclic hydrocarbons. In: Clayton GD, Clayton FG, eds. Patty's industrial hygiene and toxicology. 3rd ed. New York: John Wiley and Sons, 1983;2b: 3243-6.

7 Schäfer von R, Schäfer W. Die percutane Resorption verschiedener Terpene-Menthol, Campher, Limonen, Isobornylacetat, $\alpha$-Pinen-aus Badezusätzen Stzen. Arzneimittelforschung 1982;1:56-8.

8 Köppel C, Tenczer J, Tönnesmann U, Schirop T, Ibe K. Acute poisoning with pine oil-metabolism of monoterpenes. Arch Toxicol 1981;49:73-8.

9 Falk A, Hagberg M, Löf A, Wigaeus-Hjelm E, Wang Z. Uptake, distribution and elimination of $\alpha$-pinene in man after exposure by inhalation. Scand $f$ Work Environ Health 1990;16:372-8.

10 Falk A, Löf A, Hagberg M, Wigaeus-Hjelm E, Wang Z. Human exposure to 3-carene by inhalation: toxicokinetics, effects on the pulmonary function and occurence of irritative and CNS-symptoms. Toxicol Appl Pharmacol irritative and CNS-sy

11 Falk Filipsson A, Löf A, Hagberg M, Wigaeus Hjelm E, Wang Z. d-Limonene exposure to humans by inhalation: uptake, distribution, elimination, and effects on the pulmonary function. If Toxicol Environ Health 1993;38: 77-88.

12 Levin J-O, Eriksson K, Falk A, Löf A. Renal elimination of verbenols in man following experimental $\alpha$-pinene inhalation exposure. Int Arch Occup Environ Health 1992; 63:571-3.

13 Grimm W, Gries H. Turpentine. In: Parnneggiani L, ed. Encyclopedia of occupational safety and health. Geneva: ILO, 1983: 2229 .

14 Brun R. Epidemiology of contact dermatitis in Geneva (1000 cases). Contact Dermatitis 1975;1:214-7.

15 Dooms-Goossens H, Degreef $H$, Holvoet C, Maertens $M$. Turpentine-induced hypersensitivity to peppermint oil. Contact Dermatitis 1977;3:304-8.

16 Löf A, Brohede C, Gullstrand E, et al. The effectiveness of respirators measured during styrene exposure in a plastic boat factory. Int Arch Occup Environ Health 1993;65: 29-34.

17 Sollenberg J, Bjurström R, Wrangskog K, Vesterberg $O$. Biological exposure limits estimated from relations between occupational styrene exposure during a workbetween occupational styrene exposure during a work-
week and excretion of mandelic and phenylglyoxylic week and excretion of mandelic and phenylglyoxylic acids in

18 Kjellberg A, Landström U, Löfstedt P, Wide P, Åkerlund E. Estimation of noise and annoyance in working environments. Arbete och Hälsa 1988;30:1-36. (In Swedish with English Summary.) 